\title{
Abecedarian: An Early Childhood Education Approach that has a Rich History and a Vibrant Present
}

\author{
Joseph Sparling ${ }^{1,2,3} \cdot$ Kimberly Meunier $^{1}$
}

Published online: 24 July 2019

(C) The Author(s) 2019

\begin{abstract}
The Abecedarian Approach was created in the early 1970s to serve as the 'educational treatment' in the Abecedarian Project, a rigorous randomized controlled trial for children of disadvantaged families. The elements of the Abecedarian Approach are Language Priority, Enriched Caregiving, Conversational Reading, and LearningGames ${ }^{\circledR}$. The Approach spans from birth to school entry and can be delivered through group child care, family child care, playgroups, and home visits. Preschool research findings showed positive effects on cognition as early as 18 months of age. School research showed improvement in reading and math achievement that persisted throughout the entire period of school enrollment. Long-term benefits for this disadvantaged sample included a fourfold improvement in their rate of university graduation. Adult-age follow-up disclosed unexpected benefits in life course variables including better health, more equitable social decision making, and reduced criminal behavior. Research on this classic early childhood approach is continuing today, and the results of two of those contemporary studies are reported in this issue of International Journal of Early Childhood.
\end{abstract}

Keywords Abecedarian Approach · Abecedarian research · Language priority · Enriched caregiving $\cdot$ Conversational reading $\cdot$ Learning games

\section{Résumé}

L'Abecedarian Approach a été créée au début des années 1970 afin de servir de «traitement éducatif » dans le cadre du projet Abecedarian, essai randomisé rigoureusement contrôlé pour enfants de familles défavorisées. Les éléments de l'Abecedarian Approach sont la priorité au langage, l'enrichissement des soins, la lecture conversation-

Joseph Sparling

sparling@unc.edu

1 Abecedarian Education Foundation, 2505 Bartlett Circle, Hillsborough, NC 27278, USA

2 Frank Porter Graham Child Development Institute, The University of North Carolina at Chapel Hill, Chapel Hill, NC 27599, USA

3 University of Melbourne, Melbourne, Australia 
nelle et les LearningGames ${ }^{\circledR}$ ('les jeux d'apprentissage'). Cette approche s'étend de la naissance à l'entrée à l'école et elle peut être mise en place en garderies de groupe, en garde en milieu familial, en groupes de jeu et visites à domicile. Les conclusions de la recherche au préscolaire révèlent des effets positifs sur la cognition dès l'âge de 18 mois. La recherche à l'école indique de meilleurs résultats en lecture et en mathématiques qui persistent sur toute la période de fréquentation scolaire. Les bénéfices à long terme pour cet échantillon défavorisé comprennent une amélioration quatre fois supérieure de son taux de diplômes universitaires. Le suivi à l'âge adulte révèle des bénéfices inattendus dans des variables de parcours de vie, notamment une meilleure santé, une prise de décisions sociales plus équitable et un comportement criminel réduit. La recherche sur cette approche classique en petite enfance se poursuit aujourd'hui et les résultats de deux de ces études contemporaines sont rapportés dans ce numéro de la Revue Internationale de l'Enfance Préscolaire.

\section{Resumen}

El Método Alfabético fue creado a comienzos de los años 70 como 'tratamiento educativo' en el Proyecto Alfabético, un estudio controlado aleatorio riguroso en niños de familias desfavorecidas. Los elementos del Método Alfabético son: Prioridad de Lenguaje, Atención Enriquecida, Lectura Conversacional, y Juegos de Aprendizaje $\left(\right.$ LearningGames ${ }^{\circledR}$ ). El Método cubre la etapa desde el nacimiento hasta el inicio escolar y puede llevarse a cabo en guarderías, grupos lúdicos, guarderías familiares y visitas domiciliarias. Los resultados de la investigación en la etapa preescolar mostraron efectos positivos en las habilidades cognitivas en edades tan tempranas como los 18 meses. La investigación en la etapa escolar mostró una mejoría en las habilidades de lectura y matemáticas, las cuales continuaron a lo largo de todo el período de participación escolar. Los beneficios a largo plazo para esta muestra de población de escasos recursos incluyeron un mejoramiento cuadruplicado en sus tasas de finalización de estudios universitarios. El seguimiento en la etapa adulta reveló beneficios sorprendentes en variables tales como mejor salud, más igualdad en la toma de decisiones en la sociedad, y una reducción del comportamiento criminal. Hoy en día se siguen desarrollando investigaciones de este Método clásico de infancia temprana y los resultados de dos de tales estudios contemporáneos se describen en esta edición de la Revista Internacional de Infancia Temprana (IJEC).

\section{Introduction}

In the 1960s and early 1970s, it was known that children from low-resource or socially disadvantaged families in the USA typically were segregated by economic circumstances in schools. These children frequently had poorer school performance than their more advantaged peers and most often did not achieve their full potential (Coleman et al. 1966). Researchers, educators, and public leaders began to focus on significant social policy questions associated with this issue: How could children from low-resource families achieve greater success in school? Could a positive early childhood experience be the key to this success? This paper describes the 
Abecedarian Approach, an important early childhood program developed in the USA in the 1970s, research on its effectiveness, and current directions. It reviews the success of this program to make a difference in the lives of children.

In 1965, as part of 'The War on Poverty,' a policy initiative by the US federal government to create a safety net for economically disadvantaged people, the Head Start program was initiated as an eight-week summer course for three- and four-year-old children from low-income families. However, the initial early research results were disappointing (Westinghouse Learning Corporation 1969). To further investigate the power of enriched early childhood experiences, a research team at the Frank Porter Graham Child Development Institute of the University of North Carolina created the Abecedarian Approach to serve as the 'educational treatment' in the Abecedarian Project, a rigorous randomized controlled trial (Ramey et al. 1976). The investigators hypothesized that providing theory-based, active, contingent experiences to children who are vulnerable or disadvantaged across the earliest years of development would significantly improve their achievement once they reached school.

\section{Abecedarian Research over the Years}

The Abecedarian Approach was delivered to children in socially disadvantaged families through an enriched, full-day, year-round child care. It had greater positive results than had been expected. The original research showed significant effects on cognitive development from as early as 18 months (Ramey and Haskins 1981), better reading and math achievement that persisted throughout the entire period of school enrollment (Campbell et al. 1998), and a fourfold improvement in the rate of university graduation (Campbell et al. 2012). Follow-up of the original study sample in adulthood revealed unexpected benefits in life course variables including improved health (Campbell et al. 2014), more equitable social decision making (Luo et al. 2018), and reduced criminal behavior (García et al. 2019).

Curriculum process factors that were found to be predictive of positive child outcomes included the number of Abecedarian activities the children received (Sparling et al. 1991) and the degree to which parents and children actively engaged in the Abecedarian experiences (Liaw et al. 1995). Further analysis highlighted a positive association between the participation levels of the children and families (days attended by child, number of home visits, and parent meetings attended) and children's cognitive progress at 2 and 3 years of age (Blair et al. 1995).

Following the original study, other scientific studies (see Table 1) employed the same educational treatment, the Abecedarian Approach. The additional studies were not traditional replications in that they not only varied the location or sample but tried to produce new knowledge by varying one or more program aspects such as method of delivery, setting, staffing, or length of treatment. These studies demonstrated that the Abecedarian Approach could be effective with additional groups including low birth weight babies (Sparling et al. 1991; Ramey et al. 1992); children with cerebral palsy (Palmer et al. 1988; Sparling 1989); children from countries other than the USA (Bann et al. 2016); and children raised in orphanages (Sparling et al. 2005). These studies also showed that 


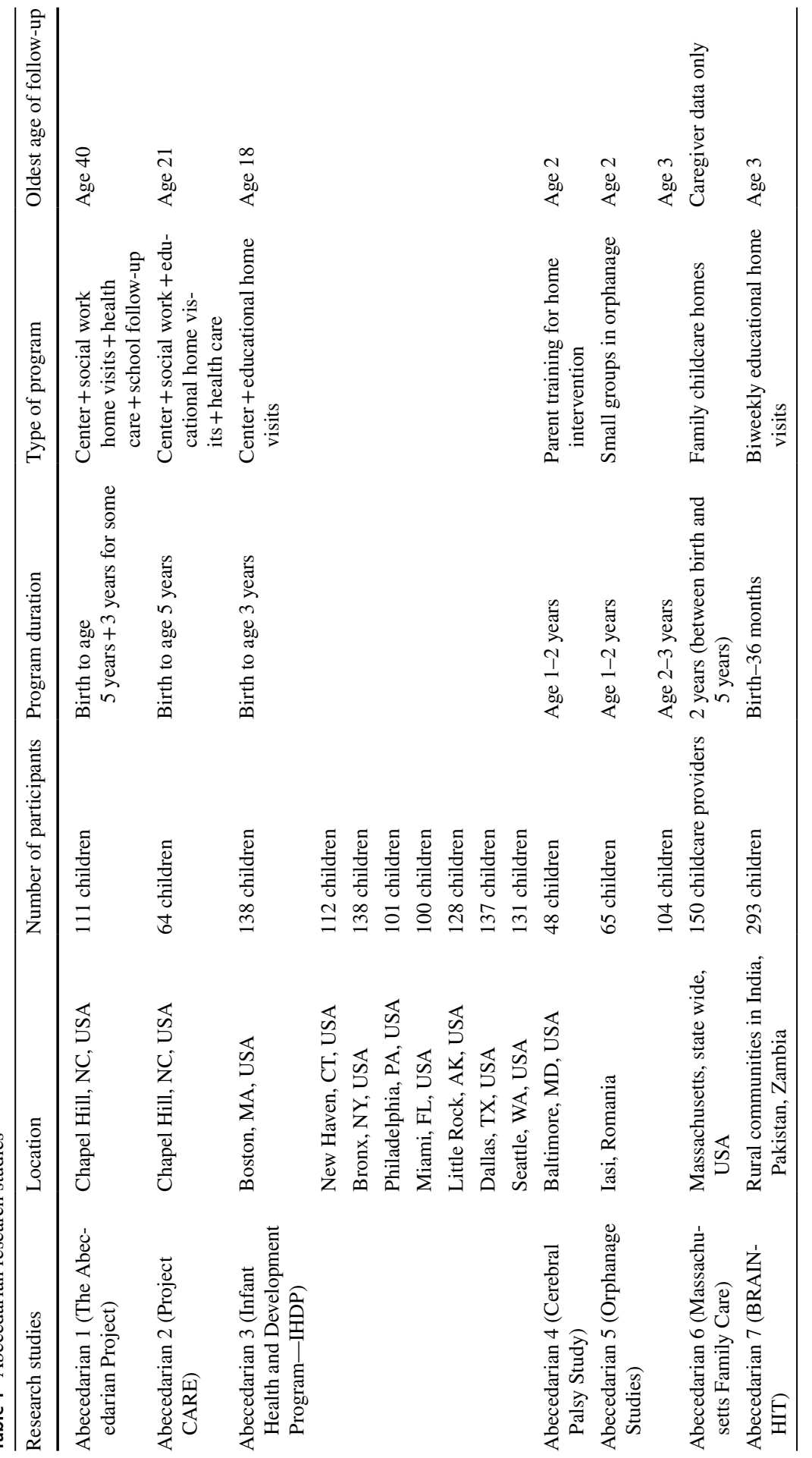




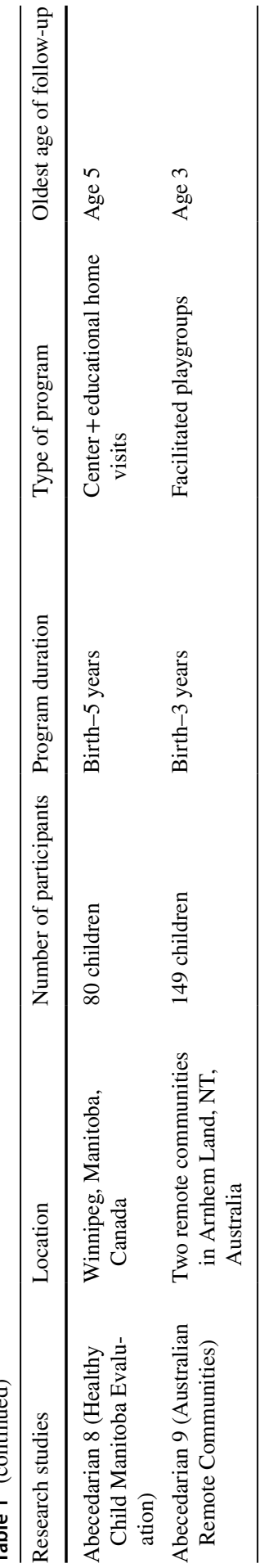


the Abecedarian Approach could be delivered not just through group child care, but through other service modalities such as home visits (Bann et al. 2016) and family child care (Collins et al. 2010). In addition, the approach was found to be effective when used in just the first 3 years of life (Sparling et al. 1991; Ramey et al. 1992).

The first three Abecedarian studies were Randomized Control Trials (RCTs) that also became longitudinal investigations. The long-term, positive results of these scientific studies are now known throughout the world and form a major part of the evidence that supports current widely held beliefs that high-quality early childhood programs are effective. Using data from the first two longitudinal studies, the economics team led by Nobel Laureate James Heckman calculated the economic return on the Abecedarian Approach at $13.7 \%$ per year (García et al. 2016).

Findings from the most recent Abecedarian Approach investigations (see Studies 8 and 9 in Table 1) are included in this issue of the International Journal of Early Childhood. The first, from Canada, was an urban application delivered through child care and home visiting. The study sample had a high representation of First Nations families and children. The second, from Australia, was delivered in remote areas and delivered through facilitated playgroups. The sample in the study was Aboriginal families and their children.

\section{The Abecedarian Approach}

The Abecedarian Approach 'educational treatment' used in these research studies is a set of strong teaching and learning strategies implemented through individualized, planned, and unplanned adult-child interactions. In creating this approach for the Abecedarian Project in the early 1970s, the program developers strove to capture the emerging scientific knowledge about how infants and young children grow and develop and to translate this technical information into playful activities and educational interactions. They attempted to create activities that could be understood and used by parents as well as by all professionals working with and caring for young children. The Abecedarian Approach incorporated many features of a stimulating home environment and some features of a high-quality childcare center. These features were enhanced by new evidence of children's role as active learners and the strength of response-contingent feedback (Finkelstein and Ramey 1977). Rich oral language and dynamic interactions were integrated into every aspect of the child's day. The theoretical underpinnings derive particularly from Vygotsky's concepts of adult-mediated activities and scaffolding (Vygotsky 1978), Piaget's developmental progression as described in his stages of cognitive development (Flavell 1963), and Scaife and Bruner's (1975) model of joint attention. Since the initial development of the intervention program, new information on brain development (Casey et al. 2000) and executive function (Blair and Diamond 2008) has become available and retrospectively provided added rationales for the Abecedarian strategies. 


\section{Core Educational Elements}

The educational program of the Abecedarian Approach is comprised of four interconnected elements for supporting and stimulating children's development: Language Priority, Enriched Caregiving, Conversational Reading, and LearningGames ${ }^{\circledR}$.

Each element is one way of supporting high-quality adult-child interaction. In the Abecedarian Approach, everything is done intentionally, frequently, and individually. This means that educators, caregivers, playgroup leaders, home visitors, and parents use specific strategies to interact with each child, informed by their observations and knowledge of that child. Each element is incorporated into the child's day multiple times, the repetition providing many opportunities for practice. Many of the interactions are one-on-one (or one adult to two children at age three and four) allowing the adult to better tailor content and responses to the child's individual needs and interests. Strategies and activities that are used in the childcare center are shared with parents for additional use in the home environment and outside of the center, thus making the approach even stronger.

\section{Language Priority}

All aspects of development contribute to the child's later success, but language is most directly linked to school performance. Therefore, the Abecedarian Approach puts a special focus or priority on language, which envelopes and guides all of the adult's interactions with the child. This is also a fundamental ingredient in the three other core Abecedarian elements.

By emphasizing language throughout the day, adults enrich the children's experiences and provide plentiful practice in listening, talking, responding, and taking turns. This helps stimulate children's language, cognitive, social, and emotional development. Language encompasses both expressive and receptive skills as well as verbal and nonverbal (e.g., print or body language) forms.

\section{Enriched Caregiving}

Caregiving activities are an integral and time-intensive portion of the day for parents and educators alike. These events such as feeding/eating, changing diapers/ toileting, bathing/washing hands, getting dressed/undressed happen many times each day in both home and center, or playgroup environments. Other regular routines and transitions occupy additional time during the day. Frequently, parents and caregivers do not think of these routines and transitions as 'educational.'

The Enriched Caregiving element of the Abecedarian Approach encourages adults to enhance the basic level of care they provide by emphasizing the social/ emotional aspect of it as well as incorporating explicit educational content into it. Parents and caregivers increase the value and power of many daily routines and transitions by recognizing and planning for them as ideal opportunities for 
rich, personalized interactions for young children. Enriched Caregiving gains its strength from its natural context, individual child focus, and many repetitions.

\section{Conversational Reading}

In the Abecedarian Approach, Conversational Reading occurs between one adult and one infant or young child. Later, when children are older (typically age 3 or above), reading sessions may involve two children at a time. The name 'conversational' emphasizes the back-and-forth, reciprocal nature of this type of reading. Every child, even the youngest baby, plays an important and active role.

Conversational Reading may not look like 'typical' book reading in a childcare center as it does not necessarily follow the text of a book and a book may not be read all the way through in one session. Furthermore, these do not need to be long interactions. Shorter, more frequent reading sessions may be more powerful. Due in part to this repetition as well as its planned and individualized nature, Conversational Reading has a special strength for developing children's vocabulary and cognitive abilities.

\section{LearningGames ${ }^{\circ}$}

Learning Games, like the other elements of the Abecedarian Approach, focus on short learning episodes involving personalized adult-child interaction. The games fit seamlessly into the day at home or in a childcare center and into a play-based approach to learning. There are 200 games in total, spread out over the first 5 years of life and covering all the developmental domains. Each game has embedded knowledge about how children develop and learn and explains why that game is important for the child's growth and learning.

Learning Games may be described as 'simple, but deep.' While the action of many of the games is simple, the significance to the child's development is profound. The games appear easy on the surface but challenge the adult to find just the right level and variation for the individual child.

\section{The Abecedarian Approach: Implementation Today and Tomorrow}

There is no rigid script or single, inalterable set of implementation standards for the Abecedarian Approach. Ultimately, each application needs to assure local fidelity to the approach, so proactive, local leadership is of great importance, especially as the approach begins to be scaled up. This also gives the Abecedarian Approach a flexibility that has made it possible to successfully apply it in multiple modes of program delivery and in a variety of countries and settings.

Getting the program into faithful, daily practice was a challenge and mission for each of the past applications of the Abecedarian Approach and will also be a mission for future successful uses of the program. Every time it is implemented, local leaders must face the question: What will make it possible for this particular group 
of professionals and parents to not only understand the program but also to put it into frequent and sustained practice? An array of recommended training procedures and resources exist, ${ }^{1}$ but these must always be adapted and made to work in the local context.

In addition to the previous and ongoing work listed in Table 1, the Approach has been adapted and implemented in regions of China, Denmark, France, Jordan, Mexico, Mongolia, and Singapore. Some of these applications are research studies while others focus on training and implementation. Each application provides new insights and creativity in making the Abecedarian Approach a widely useful resource to support positive child development with long-lasting, life course benefits.

Acknowledgements The authors acknowledge Craig Ramey as the initiator and chief scientist of the initial Abecedarian research studies. His early insights into important societal issues related to unequal family resources and unequal educational opportunity inspired all the following Abecedarian studies. We also acknowledge many additional investigators and implementers who sought and still are seeking to extend our understanding of how to apply the Abecedarian Approach in new settings and with new populations.

\section{Compliance with Ethical Standards}

Conflict of interest Kimberly Meunier is the author of Abecedarian Approach training programs. Joseph Sparling with Craig Ramey is the author of the Abecedarian Approach program described in this paper and used in the research studies summarized in this paper. Neither Meunier nor Sparling receives royalties or other benefits from the use of the Abecedarian Approach or training on the Abecedarian Approach.

Open Access This article is distributed under the terms of the Creative Commons Attribution 4.0 International License (http://creativecommons.org/licenses/by/4.0/), which permits unrestricted use, distribution, and reproduction in any medium, provided you give appropriate credit to the original author(s) and the source, provide a link to the Creative Commons license, and indicate if changes were made.

\section{References}

Bann, C. M., Wallander, J. L., Do, B., Thorsten, V., Pasha, O., Biasini, F. J., et al. (2016). Home-based early intervention and the influence of family resource on cognitive development. Pediatrics, 137(4), $1-9$.

Blair, C., \& Diamond, A. (2008). Biological processes in prevention and intervention: The promotion of self-regulation as a means of preventing school failure. Development and Psychopathology, 20(3), 899-911.

Blair, C., Ramey, C. T., \& Hardin, J. M. (1995). Early intervention for low-birth-weight, prematureinfants-Participation and intellectual-development. American Journal on Mental Retardation, 99(5), 542-554.

Campbell, F., Conti, G., Heckman, J. J., Moon, S. H., Pinto, R., Pungello, E., et al. (2014). Early childhood investments substantially boost adult health. Science, 343(6178), 1478-1485. https://doi. org/10.1126/1248429.

Campbell, F. A., Helms, R., Sparling, J. J., \& Ramey, C. T. (1998). Early childhood programs and success in school: The Abecedarian study. In W. S. Barnett \& S. S. Boocock (Eds.), Early care and education for children in poverty: Promises, programs and long-term results (pp. 145-166). New York, NY: State University of New York Press.

\footnotetext{
${ }^{1}$ For information on research, training, and resources, see these Abecedarian Web sites: http://AEFgl obal.org, https://3a.education.unimelb.edu.au, https://earlydevelopmentresources.com, http://abc.fpg.unc. edu.
} 
Campbell, F. A., Pungello, E. P., Burchinal, M., Kainz, K., Pan, Y., Wasik, B. H., et al. (2012). Adult outcomes as a function of early childhood educational intervention: An Abecedarian Project follow-up. Developmental Psychology, 48(4), 1033-1043. https://doi.org/10.1037/a0026644.

Casey, B. J., Giedd, J. N., \& Thomas, K. M. (2000). Structural and functional brain development and its relation to cognitive development. Biological Psychology, 54(1-3), 241-257.

Coleman, J. S., Campbell, E. Q., Hobson, C. J., McPartland, F., Mood, A. M., Weinfeld, F. D., et al. (1966). Equality of educational opportunity. Washington, DC: U.S. Government Printing Office.

Collins, A., Goodson, B., Luallen, J., Fountain, A. R., \& Checkoway, A. (2010). Evaluation of child care subsidy strategies: Massachusetts family child care study, OPRE 2011-1. Washington, DC: OPRE, Administration for Children and Families, US Department of Health and Human Services.

Finkelstein, N. W., \& Ramey, C. T. (1977). Learning to control the environment in infancy. Child Development, 48, 806-819.

Flavell, J. H. (1963). The university series in psychology. The developmental psychology of Jean Piaget. Princeton, NJ: D Van Nostrand.

García, J. L., Heckman, J. J., Leaf, D. E., \& Prados, M. J. (2016). The life-cycle benefits of an influential early childhood program (Working Paper 22993). Cambridge, MA: National Bureau of Economic Research.

García, J. L., Heckman, J. J., \& Ziff, A. L. (2019). Early childhood education and crime. Infant Mental Health Journal, 40, 141-151. https://doi.org/10.1002/21760.

Liaw, F., Meisels, S. J., \& Brooks-Gunn, J. (1995). The effects of experience of early intervention on low birth weight, premature children: The Infant Health and Development Program. Early Childhood Research Quarterly, 10, 405-431.

Luo, Y., Hétu, S., Lohrenz, T., Hula, A., Dayan, P., Ramey, S. L., et al. (2018). Early childhood investment impacts social decision-making four decades later. Nature Communications, 9(1), 1-10.

Palmer, F. B., Shapiro, B. K., Wachtel, R. C., Allen, M. C., Hiller, J. E., Harryman, S. E., et al. (1988). The effects of physical therapy on cerebral palsy. A controlled trial in infants with spastic diplegia. New England Journal of Medicine, 318, 803-808.

Ramey, C. T., Bryant, D. M., Wasik, B. H., Sparling, J. J., Fendt, K. H., \& LaVange, L. M. (1992). The infant health and development program for low birthweight, premature infants: Program elements, family participation, and child intelligence. Pediatrics, 3, 454-465.

Ramey, C. T., Collier, A. M., Sparling, J. J., Loda, F. A., Campbell, F. A., Ingram, M. D., et al. (1976). The Carolina Abecedarian project: A longitudinal and multidisciplinary approach to the prevention of developmental retardation. In T. D. Tjossem (Ed.), Intervention strategies for high risk infants and young children (pp. 629-665). Baltimore, MD: University Park Press.

Ramey, C. T., \& Haskins, R. (1981). The modification of intelligence through early experience. Intelligence, 5, 5-19.

Scaife, M., \& Bruner, J. (1975). The capacity for joint visual attention in the infant. Nature, 253, $265-266$.

Sparling, J. (1989). Narrow- and broad-spectrum curricula, two necessary parts of the special child's program. Infants and Young Children, 1(4), 1-8.

Sparling, J., Dragomir, C., Ramey, S., \& Florescu, L. (2005). An educational intervention improves developmental progress of young children in a Romanian orphanage. Infant Mental Health Journal, 26(2), 127-142.

Sparling, J., Lewis, I., Ramey, C. T., Wasik, B. H., Bryant, D. M., \& LaVange, L. M. (1991). Partners, a curriculum to help premature, low-birthweight infants get off to a good start. Topics in Early Childhood Special Education, 11(1), 36-55.

Vygotsky, L. S. (1978). Mind in society: The development of higher psychological processes. Cambridge, MA: Harvard University Press.

Westinghouse Learning Corporation. (1969). The impact of Head Start: An evaluation of the effects of Head Start on children's cognitive and affective development. Springfield, VA: Customer Services Clearinghouse, U.S. Dept. of Commerce.

Publisher's Note Springer Nature remains neutral with regard to jurisdictional claims in published maps and institutional affiliations. 